ORIGINAL RESEARCH PAPER

\title{
USE OF THE LACTOCOCCUS LACTIS IO-1 FOR DEVELOPING A NOVEL FUNCTIONAL BEVERAGE FROM COCONUT WATER
}

\author{
OLAIDE OLAWUNMI AJIBOLA ${ }^{1,2 *}$, SAMUEL LIHAN², AHMAD HUSAINI ${ }^{1}$, \\ ROSMAWATI SAAT ${ }^{1}$, FAZIA MOHAMAD SINANG ${ }^{1}$, IDRIS ADEWALE AHMED ${ }^{3}$, \\ WAHAB A. ABIDEEN ${ }^{4}$ \\ ${ }^{1}$ Faculty of Resource Science \& Technology, Universiti Malaysia Sarawak, 94300 Kota Samarahan. \\ ${ }^{2}$. Institute of Biodiversity and Environmental Conservation, University Malaysia Sarawak, 94300 Kota \\ Samarahan, \\ ${ }^{3}$ Center for Natural Products Research and Drug Discovery, University of Malaysia, 50603 Kuala Lumpur. \\ 4 Department of Microbiology, Faculty of Basic and Applied Science, Osun State University, Osogbo, Nigeria. \\ *Corresponding author: olaideajibola@gmail.com
}

Received on 3 March 2020

Revised on 7 May 2020

\begin{abstract}
The goal of this work was to add value to the coconut water $(\mathrm{CW})$ by fermentation with the potential probiotic Lactococcus lactis subsp lactis IO-1 in order to produce fermented $\mathrm{CW}$ beverages. Unpasteurized coconut water (UPW) was fermented with Lactococcus lactis subsp lactis $\mathrm{IO}-1$ for $48 \mathrm{~h}$ at $30^{\circ} \mathrm{C}$, and the viable cell counts, total acidity, $\mathrm{pH}$, degree of polymerization, antioxidant activity, antibacterial bioassay and lethality bioassay were studied at 24 and $48 \mathrm{~h}$. We revealed that the fermentation process of UPW with probiotic L. lactis IO-1 increased the viable cell counts. The total phenolic compound exhibited a higher antioxidative ability in fermented UPW at $48 \mathrm{~h}(65.79 \mu \mathrm{g} / \mathrm{mL}$ gallic acid equivalence). The fermented UPW exhibited the highest ferric reducing antioxidant power (FRAP) and 2,2-diphenyl-2-picrylhydrazyl (DPPH) radical scavenging abilities at $48 \mathrm{~h}$ (67.62 and 63.03\%), The culture extracted from fermented UPW inhibited all the tested pathogenic foodborne such as Listeria monocytogenes, Salmonella typhi, Staphylococcus aureus, and Escherichia coli, although the degree of antagonistic varied between the pathogens. Furthermore, fermented UPW extract sample at $48 \mathrm{~h}$, exhibited lower potent activity against the brine shrimp with $\mathrm{LC}_{50}$ values $(7158.2 \mu \mathrm{g} / \mathrm{mL})$. Comparatively, pasteurized coconut water (PCW90) fermented by Lactococcus lactis subsp lactis IO-1 produced a fermented beverage PCW90 with similar properties as the fermented UPW. Adding $0.4 \%(\mathrm{w} / \mathrm{v})$ of coconut flavor and $20 \%$ pure honey $(\mathrm{v} / \mathrm{v})$ into the fermented CW gave the beverage a better taste. The obtained results showed that the CW product fermented by Lactococcus lactis subsp lactis IO-1 may be used as a novel functional beverage comprising both probiotics and electrolytes, which can serve as a good vehicle for developing a wider range of novel products.
\end{abstract}

Keywords: Antibacterial activity, antioxidant activity, brine shrimp lethality test, coconut water, cytotoxicity.

https://doi.org/10.35219/foodtechnology.2020.1.07 


\section{Introduction}

Coconut water $(\mathrm{CW})$ is considered as tender coconut water (TCW) or matured coconut water (MCW), based on maturity, cultivation areas and subsequently, storage and post-harvesting processing (Zhang et al., 2018). TCW is commonly consumed as a sport beverage in the tropics (Giri et al., 2018), while MCW is mostly discharged because only coconut meats are utilized for different culinary purposes. Besides, $\mathrm{CW}$ is low in fat and calories, but rich in magnesium, calcium, enzymes, vitamin $\mathrm{C}$ and vitamin $\mathrm{B}$ and making it a good substitute for artificial sports beverages to replace the electrolytes after exercise (Giri et al., 2018). Edible coconut parts and various value-added products comprise a high content of flavonoid and phenolic compounds with antioxidant capacity (Arivalagan et al., 2018). Furthermore, (-)-epicatechin and (+)-catechin were reported in CW (Kantanchote et al., 2017). There are few current studies on fermentation, particularly fermentation with the probiotic strains (Prado et al., 2015). In this study, more attention was given to the use of lactic acid bacteria (LAB) to develop a value-added $\mathrm{CW}$ as a probiotic beverage.

Functional beverages are described as alcoholic-free beverages fortified with an ingredient like herbs, minerals, vitamins, sugars, or additional raw vegetables or probiotics that give specific health qualities beyond those found in other general food sources (Kantanchote et al., 2017). Lactic acid bacteria have been widely accepted as safe (GRAS) and played a key role in fermented beverages and food production (Kantachote et al., 2017). Consequently, lactic acid fermentation (LAF) is a natural method to improve the amount of the polyphenol compounds in feedstocks that are beneficial to consumer's health.

Lactococcus lactis subsp lactis IO-1 has been successfully utilized as a starting culture to obtained lactic acid from lactose and hydrolysis of citric acid and casein by fermentative pathway (Samaržija et al., 2001). The strain is regarded as safe by scientists because it has probiotic properties including the production of bacteriocins (Kato et al., 2012). The unique characteristic of this strain as compared to other LABs is its ability to ferment xylose to generate L-lactic acid (Kato et al., 2012).

Aside from the maturity stage and cultivar types of fruits, bio-composition and bioactive components in fruit beverages are heavily influenced by post-harvesting processing (Talcott et al., 2003). In addition, the pasteurization process may increase antioxidant abilities due to the release of compounds that possess antioxidant activity from the cell matrix, while in some cases it may lead to the deterioration of antioxidant activity (Farnworth et al., 2001). However, several $\mathrm{LAB}$ strains are being recorded for their capabilities to produce antioxidant and antimicrobial bioactivities (Giri et al., 2018) and can reduce the level of toxicity (Chelule et al., 2010). For example, plants like Houttuynia cordata fermented with probiotic Lactobacillus spp. have been reported to be less toxic and safe for human consumption than non-fermented $H$. cordata (Chaiyasut et al., 2018). Thus, in this work, the focus was on the development of functional CW using L. lactis IO-1, with the goal of enhancing the nutritional benefits of this beverage. Additionally, 
alterations were analyzed in the degree of polymerization, total acidity, antioxidant ability, toxicity activity and antibacterial activity of the fermented CW.

\section{Materials and methods}

\section{Chemicals}

Chemical compounds such as DPPH (2,2-Diphenyl picrylhydrazyl), FolinCiocalteu phenol, Sodium chloride, Potassium chloride, Disodium hydrogen phosphate, Potassium dihydrogen phosphate, Hydrochloric acid, Gallic acid, and Ascorbic acid reagents were purchased from Sigma Aldrich (St. Louis, MO, USA). Potassium ferricyanide, and Ferric chloride was purchased from Merck (KGaA, 64271 Darmstadt, Germany), Trichloroacetic acid, Sodium hydroxide, Sodium carbonate, Sodium phosphate monobasic, and Sodium carbonate were purchased from J.T Baker (Mallinckrodt Baker, Inc. Philipsburg, USA). Methanol solvent was purchased from Fisher Scientific (Pittsburgh, PA). Other chemical reagents were of analytical grades and were purchased from local suppliers.

\section{Microorganisms and cultivation conditions}

The microorganism used for fermentation was Lactococcus lactis IO-1. The strain was originated from the Japanese Microbe collection, JCM 7638. IO-1 strain stock cultivation was stored at $-40^{\circ} \mathrm{C}$ in $2 \mathrm{~mL}$ of vials comprising of $30 \%(\mathrm{v} / \mathrm{v})$ glycerol. L. lactis IO-1 strain had previously been isolated by Chinachoti et al. (1998) and its potential probiotic properties in vitro were reported (Kato et al., 2012). Strain IO-1 (obtained from Biochemistry laboratory, Universiti Malaysia Sarawak,) was thrice sub-cultured to obtain an active cell culture for preparation of inoculum by inoculating it into the artificial broth (comprising $20 \mathrm{~g}$ glucose and $5 \mathrm{~g}$ yeast extract per L) and incubating at $37^{\circ} \mathrm{C}$ for $18 \mathrm{~h}$. To prepare a starting culture, the cell was harvested by centrifugation at $7500 \times \mathrm{g}$ for $12 \mathrm{~min}$ and washed once with $0.85 \%$ sodium chloride. Subsequently, the culture was diluted with sterile $\mathrm{CW}$ to obtain optical density $\mathrm{OD}_{570}=0.39$, using a UV-1601 spectrophotometer (Shimadzu Co., Kyoto, Japan) at a wavelength of $570 \mathrm{~nm}$, of approx. $10^{8} \mathrm{CFU} / \mathrm{mL}$ (based on a preestablished calibration curve of optical density against viable counts $(\mathrm{CFU} / \mathrm{mL})$ using standard plate count method), for use as a starter cell culture (CarvajalZarrabal et al., 2009).

The test microorganisms used for antibacterial activity were the well-known potential pathogenic foodborne bacteria as follows: Listeria monocytogenes ATCC $^{\circledR} 33090^{\mathrm{TM}}$, Escherichia coli (Migula) Castellani and Chalmers ATCC $^{\circledR}$ $25922^{\mathrm{TM}}$, Staphylococcus aureus subsp. aureus Rosenbach ATCC ${ }^{\circledR} 25923^{\mathrm{TM}}$ and Salmonella typhimurium ATCC ${ }^{\circledR} 14028^{\mathrm{TM}}$ (Microorganisms were collected from the stock of the Virology laboratory, Faculty of Resource Science Technology of University Malaysia Sarawak). The test organisms were maintained on nutrient agar slopes and kept in a refrigerator at $4^{\circ} \mathrm{C}$. A $100 \mathrm{~mL}$ aliquots of nutrient broth were inoculated with the culture of test microorganisms using a loop and then incubated at $37^{\circ} \mathrm{C}$ for $18 \mathrm{~h}$. 


\section{Sample preparation and fermentation}

Harvested coconut fruits aged between seven and nine months were purchased from the farm market in Samarahan, Sarawak, Malaysia Borneo. The CW used in this research was obtained by perforating the fruit with a sterile stainless steel knife after the main epicarp has been washed and cleaned with running tap water. The water from 25 coconut fruits was collected and had an initial average of $4.78 \pm 0.16$ $\mathrm{pH}, 15.42 \pm 0.02 \mathrm{~g} / \mathrm{L}$ reducing sugar, $41.12 \pm 0.73 \mathrm{~g} / \mathrm{L}$ total sugar and $6.7 \pm 0.29$ $\mathrm{g} / \mathrm{L}$ total soluble solids. To prepare the $\mathrm{CW}$ medium, suspended solids in $\mathrm{CW}$ were pre-filtered with a $0.8 \mu \mathrm{m}$ polysulfone filter (TISH scientific, USA) before filtering with $0.65 \mu \mathrm{m}$ filter paper (TISH scientific, USA). It was then dispensed into sterilized transparent glass bottles, sealed immediately for unpasteurized samples (UPW) and then, pasteurized at $90^{\circ} \mathrm{C}$ for $5 \mathrm{~min}$ (PCW90) in a thermostatic water bath (Memmert, Schwabach, Germany) and then refrigerated at 4 until required for analyses (Ajibola et al., 2020). The pH of the two samples (UPW and PCW90) was adjusted to 6.7 with $6 \mathrm{M} \mathrm{NaOH}$ to achieve the optimum $\mathrm{pH}$ for the growth of $L$. lactis in the prepared medium. Both the UPW and PCW90 samples $(800 \mathrm{~mL})$ were inoculated with a $0.5 \%(\mathrm{v} / \mathrm{v})$ pure culture of L. lactis $\left(10^{7.5} \mathrm{CFU} / \mathrm{mL}\right)$. The fermentation was conducted in triplicate at $30^{\circ} \mathrm{C}$ for $48 \mathrm{~h}$ and samplings were done at every $24 \mathrm{~h}$ to check the required properties such as: viable cell counts, $\mathrm{pH}$, total acidity. In addition, the degree of polymerization (DP) was also investigated to confirm the preliminary results; while viable cells were counted every week for 4 weeks at $4{ }^{\circ} \mathrm{C}$.

Crude extracts were obtained from the fermented samples according to the method adapted from Mahayothee et al. (2016). The extracted fermented samples were used to evaluate various bioassays.

\section{Microbiological analysis}

The viable cell counts of $L$. lactis were estimated by standard plate count technique (Mueller Hinton agar medium, $48 \mathrm{~h}$ incubation at $30{ }^{\circ} \mathrm{C}$ ) as reported by Nematollahi et al. (2016).

\section{Analytical method}

The change in $\mathrm{pH}$ was determined by $\mathrm{pH}$ meter (MW 102, USA). The total titrable acidity (\%) was analyzed by titrating the samples with $0.1 \mathrm{~N} \mathrm{NaOH}$ (Nematollahi et al., 2016).

The degrees of polymerization (DP) of the fermented samples were estimated according to the concentration of total sugar (TSC) and reducing sugar (RSC). The Anthrone test (Loewus et al., 1952) was employed to determine TS, whereas the dinitrosalicylic acid assay (Miller et al., 1957) was employed to read the RSC. The DP was estimated from the concentration of TSC divided by the concentration of RSC.

The antioxidant ability of the fermented samples was assessed by the following assays: Ferric reducing power activity (FRAP), 2,2-diphenyl-2-picrylhydrazyl (DPPH) radical assay and total phenolic content employing the Folin-Ciocalteu 
bioassay according to the assay adopted by Oyaizu et al. (1986) and Mahayothee et al. (2016).

The antibacterial bioassay of the fermented samples was examined by using the agar well diffusion bioassay as reported by Garcia et al. (2016). Prior to each test, the fermented samples (UPW/PCW90) were diluted in sterile water $(10 \mathrm{mg} / 2 \mathrm{~mL})$ and then $50 \mu \mathrm{L}$ of each aliquot of aqueous culture extracts were applied to newly inoculated plates.

The lethality bioassay of the fermented samples was examined using brine shrimp lethality bioassay according to the method of Otang et al. (2013). The eggs of brine shrimp (Artemia salina) nauplii were hatched in aerated seawater (SW) for $24 \mathrm{~h}$ at room temperature. The active larvae hatched were attracted to the direction of light, they were chosen and treated with both fermented samples extracts. Stock solutions $(20 \mathrm{mg} / 2 \mathrm{~mL}$ ) of the each fermented sample extracts (UPW/PCW90) were prepared in Dimethyl sulfoxide (DMSO), diluted into different concentrations (1-500 $\mu \mathrm{g} / \mathrm{mL}$ ). A solution of $0.5 \mathrm{ml}$ of DMSO and $4.5 \mathrm{~mL}$ of SW was used as negative control while $5 \mathrm{mg}$ of thymol in $5.0 \mathrm{~mL}$ of SW was taken as a positive control. Ten brine shrimps were introduced into each triplicate vials containing $5 \mathrm{~mL}$ of solution and control and incubated; the effect of both fermented extracts at $24 \mathrm{~h}$ interval was monitored by examining the live larvae after $24 \mathrm{~h}$ of treatment. The death rate of the larvae showed cytotoxicity of the fermented test samples.

\section{Sensory evaluation}

Both fermented CW (UPW and PCW90) samples at 28 days of storage $\left(4^{\circ} \mathrm{C}\right)$ were sensory analysis determined by 10 trained panelists using 7-point hedonic scale test based on the following parameters; flavor, clearness, odor, color, and overall acceptance. The result of the sensory analysis showed no significant change in all parameters analyzed for UPW and PCW90 beverages produced by the IO-1 strain. Fermented UPW was further analyzed for its sensory analysis by supplementing with $20 \%$ honey $(\mathrm{v} / \mathrm{v})$ for formulation B and fermented UPW with the addition of $20 \%$ honey $(\mathrm{v} / \mathrm{v})$ and $0.5 \%(\mathrm{w} / \mathrm{v})$ coconut flavor for formulation C (Apex Flavour Inc, Belcamp, USA). The score was presented on a seven-point hedonic scale varying from 1-being dislike, 7- like very much.

\section{Statistical analysis}

All tests in this study were conducted in triplicate; the data for all variables were tested using ANOVA. The mean $\overline{(x)} \pm$ Standard error (S.E) were presented. Statistical significance was determined using Tukey's test and the $p$-value was < 0.05 was considered to be significant. The determination of the average death of the brine shrimp at different concentrations of the extracts and concentration that kills $50 \%\left(\mathrm{LC}_{50}\right)$ of the A. salina nauplii were made using Microsoft Excel and probit analysis on statistical software SPSS. 


\section{Results and discussion CW fermentation}

Changes in viable cell count, total acidity, $\mathrm{pH}$ and DP in UPW or PCW90 fermented by L. lactis IO-1 are shown in table 1.

Table 1 Changes in physicochemical and microbiological parameters during fermentation of coconut water in UPW and PCW90 media with Lactococcus lactis subsp. lactis IO-1.

\begin{tabular}{llll}
\hline Parameter & $\begin{array}{l}\text { Fermentation } \\
\text { time }(\mathrm{h})\end{array}$ & UPW & PCW90 \\
\hline Viable cell count & 0 & $7.56 \pm 0.01^{\mathrm{a}}$ & $7.52 \pm 0.01^{\mathrm{a}}$ \\
$(\log$ CFU/mL) & 24 & $9.23 \pm 0.02^{\mathrm{b}}$ & $8.73 \pm 0.01^{\mathrm{b}}$ \\
$\mathrm{pH}$ & 48 & $9.29 \pm 0.01^{\mathrm{b}}$ & $8.85 \pm 0.02^{\mathrm{c}}$ \\
& 0 & $6.80 \pm 0.01^{\mathrm{a}}$ & $6.80 \pm 0.00^{\mathrm{a}}$ \\
& 24 & $3.72 \pm 0.01^{\mathrm{b}}$ & $4.21 \pm 0.01^{\mathrm{b}}$ \\
& 48 & $3.28 \pm 0.01^{\mathrm{c}}$ & $3.43 \pm 0.00^{\mathrm{c}}$ \\
Total acidity (\%) & & & \\
& 0 & $0.25 \pm 0.00^{\mathrm{a}}$ & $0.25 \pm 0.00^{\mathrm{a}}$ \\
& 24 & $0.88 \pm 0.04^{\mathrm{b}}$ & $0.80 \pm 0.02^{\mathrm{b}}$ \\
Degree of polymerization & 0 & $0.98 \pm 0.01^{\mathrm{c}}$ & $0.90 \pm 0.00^{\mathrm{c}}$ \\
$(\mathrm{DP})$ & 24 & $2.76 \pm 0.03^{\mathrm{a}}$ & $2.73 \pm 0.03^{\mathrm{a}}$ \\
& 48 & $4.32 \pm 0.03^{\mathrm{b}}$ & $4.60 \pm 0.04^{\mathrm{b}}$ \\
\hline
\end{tabular}

Results are presented as mean \pm S.E $(n=3)$. Non-identical superscripts within the same column represent significant differences at $p<0.05$. UPW (UPW, initial $\mathrm{pH} 6.7$, inoculums size $7.5 \log$ CFU/mL). PCW90 (PCW90, initial pH 6.7, inoculums size $7.5 \log \mathrm{CFU} / \mathrm{mL}$ )

Both fermentation processes (UPW and PCW90) had a dramatic increase of viable cell counts after $24 \mathrm{~h}$ of fermentation and no remarkable difference until $48 \mathrm{~h}$ for the UPW but a significant change for PCW90.This corresponded to a significant increase of the total acidity with a significant fall of $\mathrm{pH}$ at $24 \mathrm{~h}$ of fermentation. The viable cell count approximately increased with $1.73 \log \mathrm{CFU} / \mathrm{mL}$ in the fermented UPW (9.29 $\log$ CFU/mL) while the increase was approximately $1.27 \mathrm{log}$ $\mathrm{CFU} / \mathrm{mL}$ in the fermented PCW90 $(8.85 \log \mathrm{CFU} / \mathrm{mL})$. The final count of the IO-1 cells in both UPW and PCW was comparable to those previously reported in young $\mathrm{CW}$ and matured $\mathrm{CW}$ after $48 \mathrm{~h}$ of fermentation with $L$. acidophilus $L 10$ and $L$. casei L26 (Lee et al., 2013) and L. plantarum DW12 (Kantachote et al., 2017). In order to accept that the samples have potential probiotic, viable cells must have a minimum of $10^{6}-10^{7} \mathrm{CFU} / \mathrm{mL}$ or $\mathrm{g}$ of product, based on a daily dose of $100 \mathrm{~mL}$ (Karimi et al., 2011). Therefore, both fermented CW in this study can be regarded as probiotic beverages since the strain IO-1 could survive well at $4{ }^{\circ} \mathrm{C}$ for 28 days. The results were consistent with those of Giri et al. (2018), who recorded that after $48 \mathrm{~h}$ fermentation of mature coconut beverage, probiotics ( $L$. casei L4) reached approximately $\log 9 \mathrm{CFU} / \mathrm{mL}$. Total acidity at $24-48 \mathrm{~h}$ of fermentation in both fermented samples (UPW and PCW90) was approximately 0.98 and $0.91 \%$ while 
the $\mathrm{pH}$ was approximately 3.20 and 3.34 , respectively. The DP values in both fermented samples significantly increased at $24 \mathrm{~h}$ and afterward slightly decreased. The various degrees of polymerization (DP3-DP8) oligodextran were studied for their abilities to support the probiotics growth and it was observed that the entire tested cell utilized majority of the DP4 and DP3 ( $\geq 80 \%$ ), with the exception of Lactobacillus rhamnosus, Lactobacillus helveticum and Bifidobacterium bifidum 02 for D8, D7, and D4 (Kantachote et al., 2017). With regard to both the fermented samples (UPW/PCW90) with DP values in the range of 4-5 might improve the growth of cell IO1 although prebiotics like FOS should be further investigated. Based on the result obtained in this study (Table 1), higher viable cell density, total acidity, and lower DP were observed in UPW compared to PCW90 during fermentation. This observation may be due to the micronutrients, such as vitamins, inorganic ions present in UPW (Prades et al., 2012; Tan et al., 2015), that supporting LAB during the $48 \mathrm{~h}$ of metabolic process.

\section{Antioxidant activity}

The presence of potential antioxidants can help to prevent oxidative damages that occur in the human body and prevent lipid peroxidation in foods (Abountiolas and Nascimento, 2018). In this present study, in addition to the scavenging inhibitory activity of both FRAP and DPPH radical assays, the total phenolic compound (TPC) was also estimated. L. lactis IO-1 significantly increased the antioxidant ability of both fermented samples (UPW / PCW90) that were detected by different assays such as FRAP, DPPH, and total phenolic compounds as they revealed a remarkable increase at $24 \mathrm{~h}$ (Figure 1a and b, and Figure 2). The results indicated that the antioxidant potential of both fermented samples were produced by strain IO-1. The results are in accordance with Giri et al. (2018), who recorded that the radical scavenging activities (RSA) of CW fermented by L. casei $\mathrm{L} 4$ for $48 \mathrm{~h}$ were $58.4 \%$ for DPPH and $69.2 \%$ for ABTS. Both fermented samples (UPW and PCW90) produced by strain IO-1 had the antioxidant ability, as observed in their abilities, to scavenge the radical FRAP+ in a range of $61.98-67.62 \%$ (figure $1 \mathrm{~A}$ ). It was observed from Figure 1A that antioxidants in both fermented samples (UPW/PCW90) were found to produce similar patterns for their relative antioxidant abilities as the maximum ability was demonstrated at $48 \mathrm{~h}$ of batch fermentation.

Figure 1B reveals that the antioxidant ability (UPW/PCW90) of the culture extracts, measured by DPPH assay was found to range between $58.99-63.03 \%$ with a similar trend for FRAP scavenging (figure 1a). Based on the DPPH method, both fermented samples can be classified for their antioxidant activities at the intermediate level like coffees (Ramadan-Hassanien, 2008).

However, the total phenolic amount of UPW culture extract exhibited a higher antioxidative ability (64.45-68.79 $\mu \mathrm{g} / \mathrm{mL}$ GAE) than PCW90 (59.93-62.05 $\mu \mathrm{g} / \mathrm{mL}$ GAE) (figure 2). Phenolic compounds, widely distributed in plants, are the most abundant antioxidants in the human diet (Giri et al., 2018). Some of them, including $(+)(-)$ epicatechin and -catechin, were detected in coconut water (Chang and $\mathrm{Wu}, 2011)$. In this present investigation, phenolic content in $\mathrm{CW}$ should be low 
as the detection for antioxidant ability at the starting of the fermentation was low (Figures 1 and 2). This supports the view that the free radical scavenging in both fermented extracts that occurred by probiotic strain IO-1 was due to other compounds rather than total phenolic contents (Figure 2). Between the studied samples, fermented UPW extract shows a higher amount of antioxidant activity and total phenolic content while lower content was observed in fermented PCW90 extract. The considerable difference between the results of antioxidant activity and phenolic content is due to inorganic acid, vitamins, L-arginine and ascorbic acid found in the UPW medium (Tan et al., 2015). It was therefore presumed that, apart from the phytochemicals released from cell-matrix, the active natural phenolic compound in UPW media could also contribute to the TPC during the fermentation process. Although, it has been proven previously that $\mathrm{CW}$ contains micronutrients, $\mathrm{L}$ - arginine and ascorbic acid (Lima et al., 2015)

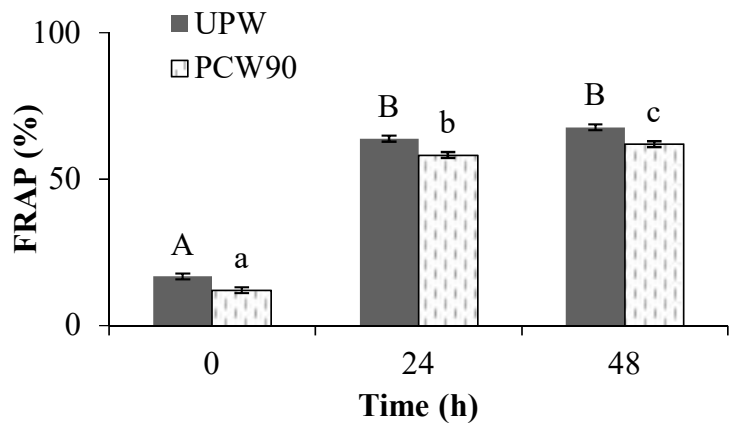

a)

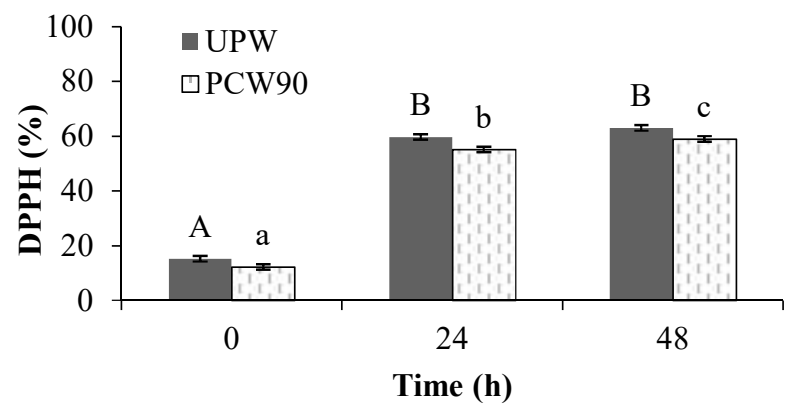

b)

Figure 1. The radical scavenging activity of UPW and PCW90 samples (A) FRAP and (B) DPPH assay. Different alphabets above bars represent significant differences $(p<0.05)$. Upper case for UPW and lowercase for PCW90.

\section{Antibacterial activity}

As indicated in table 2, no significant differences were detected between antimicrobial activities of both fermented samples (UPW/PCW90) against the growth of typical foodborne pathogenic bacteria. 


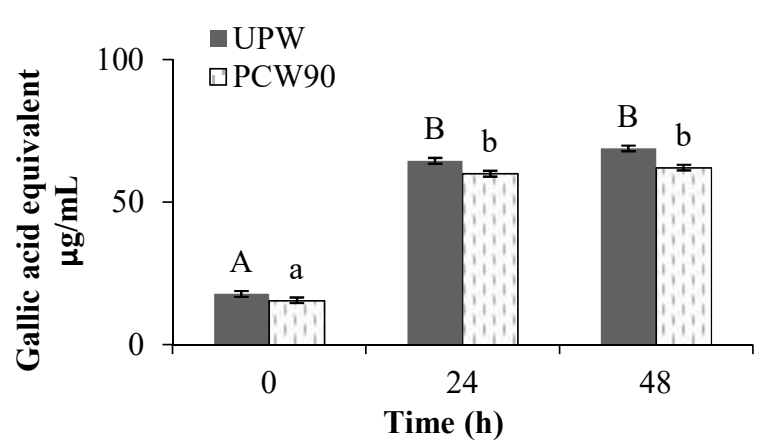

Figure 2. Total phenolic content (gallic acid equivalent: GAE) in fermented samples fermented with L. lactis IO1. Different alphabets (ABC for UPW; abc for PCW90) above bars represent the significant differences $(p<0.05)$.

Table 2. Antibacterial bioactivity of the fermented samples.

\begin{tabular}{lllll}
\hline $\begin{array}{l}\text { Test } \\
\text { microorganism }\end{array}$ & \multicolumn{2}{l}{ UPW (zone inhibition, mm) } & \multicolumn{2}{l}{ PCW90 (zone inhibition, mm) } \\
\hline & $24 \mathrm{~h}$ & $48 \mathrm{~h}$ & $24 \mathrm{~h}$ & $48 \mathrm{~h}$ \\
$\begin{array}{l}\text { Listeria } \\
\text { monocytogenes }\end{array}$ & $7.20 \pm 0.23$ & $8.30 \pm 0.11$ & $7.10 \pm 0.15$ & $8.20 \pm 0.60$ \\
$\begin{array}{l}\text { Staphylococcus } \\
\text { aureus }\end{array}$ & $5.97 \pm 0.30$ & $7.17 \pm 0.19$ & $5.80 \pm 0.32$ & $7.13 \pm 0.12$ \\
$\begin{array}{l}\text { Salmonella typhi } \\
\text { Escherichia coli }\end{array}$ & $4.60 \pm 0.57$ & $5.47 \pm 0.15$ & $4.52 \pm 0.14$ & $5.43 \pm 0.18$ \\
\hline
\end{tabular}

No antibacterial bioactivity was reported at the starting of the batch fermentation process $(\mathrm{t}=0)$.

The result indicated that both UPW and PCW90 fermented samples inhibited the growth of all tested microbes and the inhibition were in the order of $L$. monocytogenes $>S$. aureus $>S$. typhi $>E$. coli. It was ascertained that there was a slight difference in the inhibitory effects of both samples against the clinically Gram-positive bacterial strain test. However, the clinically Gram-negative bacterial strain, S. typhi, was more sensitive to UPW/PCW90 culture extracts compared with strains tested. Also, the results showed that $E$. coli revealed a higher resistance. The efficacy of the antimicrobial activity against all tested pathogenic foodborne microbes in this study was comparable to that of the fermented $\mathrm{CW}$ beverage, which was incubated for $72 \mathrm{~h}$ using L. plantarum DW12 as a starter culture (Kantachote et al., 2017). The antibacterial activity of fermented food-beverage was mainly associated with the acidity acid of the beverages as no inhibition against the growth of all target microorganisms at the starting of fermentation (Table 2). The major compound in the fermented food-beverage extract from either the UPW or PCW90 was organic acid as the total acidity was approximately $0.90 \%$. However, other polyphenol constituents present in the beverage extract may be involved in the antimicrobial action. 


\section{Toxicity against brine shrimp}

The brine shrimp lethality test (BSLT) is among the preliminary toxicity tests based on the ability to kill laboratory-cultured brine shrimp. BSLT is a reliable, fast and cheap bioassay for testing the bioactivity of the fermented beverage extracts. The determination of the lethal concentration of $50 \%\left(\mathrm{LC}_{50}\right)$ was based on the average death of brine shrimp (Artemia salina) after $24 \mathrm{~h}$ of using probits analysis technique (Table 3).

Table 3. Average death of $A$. salina nauplii at different concentrations of fermented samples at $24 \mathrm{~h}$ interval.

\begin{tabular}{|c|c|c|c|c|c|c|c|c|}
\hline \multirow{2}{*}{$\begin{array}{l}\text { Fermented } \\
\text { samples }\end{array}$} & \multicolumn{7}{|c|}{$\begin{array}{c}\text { Average death of } A \text {. salina nauplii } \\
\text { Concentration }(\mu \mathrm{g} / \mathrm{mL})\end{array}$} & \multirow{2}{*}{$\begin{array}{c}\mathrm{LC}_{50} \\
(\mu \mathrm{g} / \mathrm{mL})\end{array}$} \\
\hline & $\begin{array}{l}\text { Time } \\
\text { (h) }\end{array}$ & 1 & 10 & 25 & 50 & 100 & 500 & \\
\hline \multirow[t]{3}{*}{ UPW } & 0 & $0.33 \pm 0.6$ & $1.00 \pm 1.0$ & $1.33 \pm 0.6$ & $1.67 \pm 1.2$ & $2.33 \pm 1.5$ & $3.00 \pm 0.0$ & 4800.5 \\
\hline & 24 & $0.00 \pm 0.0$ & $0.67 \pm 0.6$ & $1.00 \pm 0.0$ & $1.30 \pm 1.2$ & $2.33 \pm 0.6$ & $2.33 \pm 0.6$ & 6567.5 \\
\hline & 48 & $0.00 \pm 0.0$ & $7.33 \pm 0.5$ & $1.33 \pm 1.1$ & $1.67 \pm 1.2$ & $2.33 \pm 0.6$ & $2.33 \pm 0.6$ & 7158.2 \\
\hline \multirow[t]{3}{*}{ PCW90 } & 0 & $0.33 \pm 0.6$ & $0.67 \pm 0.6$ & $1.33 \pm 1.5$ & $2.00 \pm 1.0$ & $2.33 \pm 2.1$ & $2.67 \pm 1.2$ & 5712.2 \\
\hline & 24 & $0.30 \pm 0.6$ & $0.67 \pm 0.6$ & $0.33 \pm 0.6$ & $1.33 \pm 1.2$ & $2.00 \pm 1.0$ & $2.33 \pm 2.1$ & 6879.8 \\
\hline & 48 & $0.00 \pm 0.0$ & $0.33 \pm 0.6$ & $0.67 \pm 1.2$ & $1.33 \pm 1.5$ & $1.33 \pm 0.6$ & $2.00 \pm 1.0$ & 8070.4 \\
\hline+ Control & & $5.00 \pm 0.8$ & $7.33 \pm 0.5$ & $10.0 \pm 0.6$ & $10.0 \pm 0.0$ & $10.0 \pm 0.0$ & $10.0 \pm 0.0$ & 10.58 \\
\hline -Control & & $0.00 \pm 0.0$ & $0.00 \pm 0.0$ & $0.00 \pm 0.0$ & $0.00 \pm 0.0$ & $0.00 \pm 0.0$ & $0.00 \pm 0.0$ & $0.00 \pm 0.0$ \\
\hline
\end{tabular}

Fermented samples with the $\mathrm{LC}_{50}$ values higher than $1000 \mu \mathrm{g} / \mathrm{mL}$ are considered non-toxic while fermented extracts with $\mathrm{LC}_{50}$ values lower than $1000 \mu \mathrm{g} / \mathrm{mL}$ are considered significantly bioactive and toxic according to Meyer's toxicity index (Meyer et al., 1982). The result of both fermented samples (UPW/PCW90) at $24 \mathrm{~h}$ interval showed a concentration dependent increment in the mortality rate of the brine shrimp nauplii. The fractions of both fermented samples extract were lower potent against the brine shrimp activity with $\mathrm{LC}_{50}$ values ranging from 4800.5 to 6879.8 respectively (Table 3). Rakić et al. (2007) suggest that reduction of toxicity during processing is influenced by the cell matrix in the degradation of hydrolysable tannins, a larger polyphenolics compound, which results in the formation of smaller degradation products, such as gallic acid, that maintains antioxidant activity. These findings were in accordance with Quiao-Won et al. (2016), which study the kombucha fermentation cytotoxicity from various substrates. Furthermore, both fermented beverage extracts (at $24 \mathrm{~h}$ interval) showed significantly lower mortality compared to a positive control (thymol). This toxicity reduction is, therefore, one of the important technological characteristics used to select a lactic acid strain starter. In addition, it can be suggested that both fermented samples suited to brine shrimp. This could be due to the absorption and metabolism of phenolic compounds by the fermenting strain, which were influenced by 1) degree of glycosylation/ acylation, 2) fundamental structure, 3) conjugation with other phenolics, 4) molecular size, 5) degree of polymerization 
and 6) solubility (Bravo, 1998). Furthermore, coconut water may contain some phenolic compounds in the stable forms of glycosides, which may be deglycoslated by probiotic LAB, which may enhance its non-cytotoxicity (Bravo, 1998).

\section{Sensory determination}

Using 10 survey subjects, we tested the acceptability of fermented UPW (formulation A), fermented UPW supplemented with $20 \%$ honey (formulation B) and fermented UPW supplemented with $20 \%$ honey and $0.4 \%(\mathrm{w} / \mathrm{v})$ coconut flavor (formulation C) (Table 4). It was observed that there were no significant changes in the appearance or color of the samples. However, the addition of $20 \%$ coconut flavor and honey (formulation C) significantly improved the sensory evaluation based on flavor, odor and the overall acceptance of the beverage, showing that formulation $\mathrm{C}$ was widely acceptable to most participated individuals in this study. These results could be due to the reduced acidity and improved aroma and sweetness of this beverage after adding coconut flavor and honey. Our findings are in agreement with those recorded by Giri et al. (2007), who revealed that the addition of coconut flavor and $15 \%$ honey enhanced the acceptance of $\mathrm{CW}$ fermented with L. casei L4. Furthermore, Kantachote et al. (2017) supplemented fermented mature $\mathrm{CW}$ with $20 \%$ honey, which enhanced the acceptance of the studied beverage. Alternatively, the fermented beverage may be supplemented with other sweetener based on desired products such as saccharin (Angelov et al., 2006), that is good for diabetic patients, and fruit ingredients to enhance their appeal to the consumer.

Table 4. Sensory determination of $\mathrm{CW}$ fermented by L. lactis $\mathrm{IO}-1$ and its modified formulation.

\begin{tabular}{llll}
\hline Parameters & Control A & Recipe B & Recipe C \\
\hline Flavor & $3.75 \pm 0.16^{\mathrm{a}}$ & $4.65 \pm 0.17^{\mathrm{b}}$ & $5.30 \pm 0.15^{\mathrm{c}}$ \\
Appearance & $3.85 \pm 0.13^{\mathrm{a}}$ & $3.95 \pm 0.14^{\mathrm{a}}$ & $4.05 \pm 0.15^{\mathrm{a}}$ \\
Odor & $3.70 \pm 0.19^{\mathrm{a}}$ & $3.85 \pm 0.13^{\mathrm{a}}$ & $4.65 \pm 0.11^{\mathrm{b}}$ \\
Color & $4.40 \pm 0.18^{\mathrm{a}}$ & $5.00 \pm 0.16^{\mathrm{b}}$ & $5.05 \pm 0.17^{\mathrm{b}}$ \\
Overall acceptance & $3.95 \pm 0.14^{\mathrm{a}}$ & $4.45 \pm 0.11^{\mathrm{b}}$ & $5.00 \pm 0.15^{\mathrm{c}}$ \\
\hline
\end{tabular}

Formulation A: (Fermented CW), Formulation B: (Fermented CW $+20 \%$ honey), Formulation C: (Formulation B + coconut flavor). Non-identical superscript alphabets with in the same row represent the significant difference, $p<0.05$.

\section{Conclusions}

It can be concluded that Lactococcus lactis IO-1 strain showed a capability for utilizing both $\mathrm{CW}$ samples. Following the $48 \mathrm{~h}$ fermentation process with L. lactis IO-1, we determined that fermented beverages contain antioxidant, antibacterial and non-cytotoxic activity. Furthermore, even after 4 weeks of refrigerated storage $\left(4^{\circ} \mathrm{C}\right)$, both fermented beverage samples retained the desired L. lactis IO-1 levels, which are in accordance with daily-recommended probiotic dose. The fermented CW supplemented with $20 \%$ pure honey and $0.4 \%(\mathrm{w} / \mathrm{v})$ coconut flavor was revealed to have the highest acceptance rate by the panelists. Further studies are 
needed for the production of inexpensive L. lactis IO-1 fermented functional beverages with several health benefits for vegetarians, lactose intolerant people, and those who are allergic to milk products.

\section{Acknowledgments}

This research was funded by a grant (grant no. FO7/SpGS/1554/2017).

\section{References}

Abountiolas, M., do Nascimento Nunes, C. 2018. Polyphenols, ascorbic acid and antioxidant capacity of commercial nutritional drinks, fruit juices, smoothies and teas. International Journal of Food Science and Technology, 53(1), 188-198.

Ajibola, O.O., Lihan, S., Hussaini, A., Saat, R., Ahmed, I.A., Abideen, W., Sinang, F.M., Sing, N.N., Adeyinka, G.C. 2020. Toxicity Assessment of Lactococcus lactis IO-1 Used in Coconut Beverages against Artemia salina using Brine Shrimp Lethality Test. Applied Food Biotechnology, 7(3), 127-134.

Angelov, A., Gotcheva, V., Kuncheva, R. and Hristozova, T. 2006. Development of a new oat-based probiotic drink. International Journal of Food Microbiology, 112, 75-80.

Arivalagan, M., Manikantan, M.R., Yasmeen, A.M., Sreejith, S., Balasubramanian, D., Hebbar, K.B., Kanade, S.R. 2018. Physiochemical and nutritional characterization of coconut (Cocos nucifera L.) haustrorium based extrudates. LWT - Food Science and Technology. 89, 1711-178.

Bravo, L. 1998. Polyphenols: Chemistry, dietary sources, metabolism, and nutritional significance. Nutrition Reviews, 56, 317-333.

Carvajal-Zarrabal, O., Nolasco-Hipólito, C., Bujang, K.B., Ishizaki, A. 2009. Production of nisin Z using Lactococcus lactis IO-1 from hydrolyzed sago starch. Journal of Industrial Microbiology and Biotechnology, 36(3), 409-415.

Chaiyasut, C., Sivamaruthi, B.S., Duangjitcharoen, Y., Kesika, P., Sirilun, S., Chaiyasut, K., Peerajan, S. 2018. Assessment of subchronic toxicity of fermented Houttuynia Cordata thunb. using rodent model system, Asian Journal of Pharmaceutical and Clinical Research, 11(8), 307-311

Chang, C., Wu, R. 2011. Quantification of $(+)$-catechin and (-)-epicatechin in coconut water by LC-MS. Food Chemistry, 126, 710-717.

Chelule, P.K., Mbongwa, H.P., Carries, S., Gqaleni, N. 2010. Lactic acid fermentation improves the quality of amahewu, traditional South African maize-based porridge. Food Chemistry, 122(3), 656-661.

Chinachoti, N., Matsusaki, H., Sonomoto, K., Ishizaki, A. 1998. Nisin Z production by Lactococcus lactis IO-1 using xylose as a carbon source. Bioscience, Biotechnology, and Biochemistry, 62(5), 1022-1024.

Farnworth, E.R., Lagace, M., Couture, R., Yaylayan, V., Stewart, B. 2001. Thermal processing, storage conditions, and the composition and physical properties of orange juice. Food Research International, 34(1), 25-30.

Garcia, E.F., Luciano, W.A., Xavier, D.E., da Costa, W.C., de Sousa, O. K., Franco, O.L., de Morias Junior, M.A., Lucena, B.T., Picao, R.C., Magnani, M., Saarela, M., de Souza, E.L. 2016. Identification of Lactic Acid Bacteria in Fruit Pulp processing Byproducts 
and Potential Probiotic Properties of Selected Lactobacillus strains. Frontier Microbiology, 7, 1371.

Giri, S.S., Sen, S.S., Saha, S., Sukumaran, V., Park, S.C. 2018. Use of a potential probiotic, Lactobacillus plantarum L7, for the preparation of a rice-based fermented beverage. Frontiers in Microbiology, 9, 473.

Kantachote, D., Ratanaburee, A., Hayisama-ae, W., Sukhoom, A., Nunkaew T. 2017. The use of potential probiotic Lactobacillus plantarum DW12 for producing a novel functional beverage from mature coconut water. Journal of Functional Foods, 1(32), 401-408.

Kato, H., Shiwa, Y., Oshima, K., Machii, M., Araya-Kojima, T., Zendo, T., ShimizuKadota, Hattori, M., Sonomoto, K., Yoshikawa H. 2012. Complete genome sequence of Lactococcus lactis IO-1, a lactic acid bacterium that utilizes xylose and produces high levels of L-lactic acid. Journal of Bacteriology, 194, 2102-2103

Karimi, R., Mortazavian, A. M., Da Cruz, A. G. 2011. Viability of probiotic microorganisms in cheese during production and storage: a review. Dairy Science \& Technology, 91(3), 283-308.

Lima, E.B.C., Sousa, C.N.S., Meneses, L.N., Ximenes, N.C., Júnior, S., Vasconcelos, G.S., Lima, N.B.C., Vasconcelos, S.M.M. 2015. Cocos nucifera (L.)(Arecaceae): A review of phytochemical and pharmacological. Brazilian Journal of Medical and Biological Research, 48(11), 953-964.

Loewus, F. A. 1952. Improvement in anthrone method for determination of carbohydrates, Analytical Chemistry, 24(1), 219-219.

Mahayothee, B., Koomyart, I., Khuwijitjaru, P., Siriwongwilaichat, P., Nagle, M., Müller, J. 2016. Phenolic compounds, antioxidant activity, and medium-chain fatty acids profiles of coconut water and meat at different maturity stages. International Journal of Food Properties, 19(9), 2041-2051.

Meyer, B.N., Ferrigni, N.R., Putnam, J.E., Jacobsen, L.B., Nichols, D.J., McLaughlin, J.L. 1982. Brine shrimp: a convenient general bioassay for active plant constituents, Planta Medica, 45(05), 31-4.

Miller, G.L. 1959. Use of dinitrosalicylic acid reagent for determination of reducing sugar, Analytical Chemistry, 31(3), 426-428.

Nematollahi, A., Sohrabvandi, S., Mortazavian, A.M., Jazaeri, S. 2016. Viability of probiotic bacteria and some chemical and sensory characteristics in cornelian cherry juice during cold storage. Electronic Journal of Biotechnology, 1 (21), 49-53.

Otang, W.M., Grierson, D.S., Ndip, N. 2013 Assessment of potential toxicity of three South African medicinal plants using the brine shrimp (Artemia salina) assay. African Journal of Pharmacy and Pharmacology, 7(20), 1272-1279.

Oyaizu, M. 1986. Studies on products of browning reaction. The Japanese Journal of Nutrition and Dietetics, 44(6), 307-315.

Prado, F.C., De Dea Lindner, J., Inaba, J., Thomaz-Soccol, V., Brar, S. K., Soccol, C. R. 2015. Development and evaluation of a fermented coconut water beverage with potential health benefits. Journal of Functional Foods, 12, 89-497.

Quiao-Won, M.E., Teves, F.G. 2018. Characteristics of Kombucha Fermentation from Different Substrates and Cytotoxicity of Tea Broth. Sustainable Food Production, 4, 11-19.

Prades, A., Dornier, M., Diop, N., Pain, J. P. 2012. Coconut water uses, composition and properties: a review. Fruits, 67(2), 87-107. 
Ramadan-Hassanien, M.F. 2008. Total antioxidant potential of juices, beverages and hot drinks consumed in Egypt screened by DPPH in vitro assay. Grasas y Aceites, 59 (3): 254-259.

Rakić, S., Petrović, S., Kukić, J., Jadranin, M., Tešević, V., Povrenović, D., ŠilerMarinković, S. 2007. Influence of thermal treatment on phenolic compounds and antioxidant properties of oak acorns from Serbia. Food Chemistry, 104 (2): 830-4.

Talcott, S.T., Percival, S.S., Pittet-Moore, J., Celoria, C. 2013. Phytochemical composition and antioxidant stability of fortified yellow passion fruit (Passiflora edulis). Journal of Agricultural and Food Chemistry, 51(4), 935-941.

Tan, T.C., Cheng, L.H., Bhat, R., Rusul, G., Easa, A.M. 2014. Composition, physicochemical properties and thermal inactivation kinetics of polyphenol oxidase and peroxidase from coconut (Cocos nucifera) water obtained from immature, mature and overly-mature coconut. Food Chemistry, 142, 121-128.

Samaržija, D., Antunac, N., Lukač Havranek, J. 2001. Taxonomy, physiology and growth of Lactococcus lactis: a review. Mljekarstvo: časopis za unaprjeđenje proizvodnje i prerade mlijeka, 51(1), 35-48.

Zhang, G., Chen, W., Chen, W., Chen, H. 2018. Improving the quality of matured coconut (Cocos nucifera Linn.) water by low alcoholic fermentation with Saccharomyces cerevisiae: antioxidant and volatile profiles. Journal of Food science and Technology, 55(3), 964-76. 